\title{
LIGA ニッケル薄膜の異方性を考慮した弾塑性特性評価*
}

\author{
石 塚丈洋*1,八戸敦司*2, 神 長 桂二*2
}

\section{Evaluation of Elastoplastic Properties of Anisotropic LIGA Nickel Films}

\author{
Takehiro ISHIZUKA*3, Atsushi HACHINOHE and Keiji KAMINAGA \\ ${ }^{* 3} 1$ st Research Center, Technical Research and Development Institute, Japan Defense Agency, \\ 2-2-1 Nakameguro, Meguro-ku, Tokyo, 153-8630 Japan
}

\begin{abstract}
Most current MEMS are using LIGA nickel films as their structural material. In order to design and produce MEMS devices accurately, it is very important to know the mechanical properties of LIGA films. However, the mechanical property evaluation for LIGA films is difficult, because LIGA films have anisotropic mechanical properties due to their microstructures and the specimens to be used in the mechanical property evaluation testing are too small to handle easily. Consequently, the evaluation methods for LIGA films have not been standardized. In this study, the Young's modulus and yield stress of LIGA nickel films are evaluated by a series of spherical indentation testing and elastoplastic analysis. Then, the effect of non-equilibrium microstructures of LIGA films on anisotropic mechanical properties is discussed.
\end{abstract}

Key Words : Anisotropy, Plasticity, Elasticity, LIGA, Nickel

\section{1. 辕 㻅}

マイクロセンサやマイクロアクチュエータなどの 異なる構成要素を集積化した微小な可動構造物である MEMS (Micro Electro Mechanical Systems) は，情報 通信, 自動車, 家電，医療機器など様々な分野で実用 化を目指して研究が進められている. MEMS 構造材 料の製造方法として半導体加工技術によるシリコンプ ロセス，放射光を用いた LIGA（Lithographie Galvanoformung Abformung) プロセスが用いられるが, 微細な 3 次元構造加工時の加工精度や再現性の観点か ら LIGA プロセスが優れているとされる (1)，(2). LIGA プロセスにより製造した MEMS 材料の材料特 性は，バルク材のそれとはしばしば異なることが報告 されている.このため, MEMS の設計においては, MEMS 材料の機械的特性を精度良く評価しておく必 要がある.一般に，バルク材の材料特性は，JS 等に 定められた規格に基づき評価され，これが設計・製造

\footnotetext{
* 原稿受付 2005 年 1 月 19 日 改定原稿受付日 2005 年 7 月 4 日.

*1 正員, 防衛庁技術研究本部第 1 研究所 (- 153-8630 東京都 目黒区中目黒 2-2-1).

*2 防衛庁技術研究本部第 1 研究所.

E-mail : ishi@jda-trdi.go.jp
}

の基淮となっている. 一方, MEMS 材料の場合, (1) 微小な試験片を取り扱うこと, (2)微小な荷重・変位を 与えこれを精密に計測すること，３薄膜構造に起因し て材料特性に異方性があること等の理由から,バルク 材に比べてその材料特性を評価することは容易ではな いが，近年，多くの研究者が，曲げ圾酫 ${ }^{(3)}$ ，(4)，引 張試験 ${ }^{(5)} \sim(9)$, 押込み試験 $(10) \sim(13)$ 等により MEMS 材料の機械的特性を明らかにするための研究 を行っている.

曲げ試験は，試験が比較的䈃単である利点を有す るが，結果の解採が引張試験のように簡単でないこと が欠点として挙げられる. また, 引張圾験は, ヤング 率や強度を直接的に測定できる利点があるが, 圾験片 の固定法が難しく，静電力により試験片を固定するな どの新しい固定法が検討されている。，一方，押込み試 験は，曲け訪験や引張試験に比べて，試験実施が容易 であることに特徵があるが，機械的特性を直接求める ことはできず，試験法の規格化はまだなされていない． そこで本研究では，MEMS 材料の異方性を考慮し た材料特性評価方法の確立を目的として, 比較的容易 に実施できる押込み試験とともに弾塑性解析を行うこ とにより，LGA プロセスにより製造した Ni 薄膜の ヤング率と降伏応力を評価した結果について報告する. 


\section{2 方 法}

21 UGA プロセス 本研究の試験片作製に用い た LUGA プロセス ${ }^{(2)}$ は，「X 線リソグラフィ」，

「電気メッキ」及び「モールディング」からなる超微 細加工技術のことで, 1980 年代にドイツのカールス ルーエ研究所にて開発された. LIGA プロセスの特徴 として,アスペクト比の高い機械構造体を製作できる こと, 高精度にマスクのパターンを転写可能でサブミ クロン精度の機械構造体が製作できることなどがあげ られる。

本プロセスの基本工程は以下のとおりである. PMMA（Polymethylmethacylat）などの感光性樹脂（フォ トレジスト）を $\mathrm{Si}$ 基板上に形成する.これに製品形 状を刻んだマスクを載せ, SR（Synchrotron Radiation）光の $\mathrm{X}$ 線を照射しマスクの形状を感光性 樹脂に転写する. これを現像し X 線を照射した部分 の感光性樹脂を除去する. 次に, 電気メッキを行い感 光性樹脂の隙間に金属を堆積させ，金属の構造体を形 成する. 続いて残りの感光性樹脂と $\mathrm{Si}$ 基板を除去す れば金属構造体が完成する. これを完成品として使用 することもできるし，これからプラスチックの型枠を 作り別の金属による電気メッキを行うこともできる.

なお，LGA プロセスに使用できるのは，電気メッキ が可能なニッケル, ニッケル合金, 銅, 鉛など様々な 金属があるが (2)，(5)，(10)，本研究では特性が良く 知られている純ニッケルを対象とした。

22 試験片 LGA プロセスにより作製した試験 片の形状と寸法を図 1 に示す. 試験片は, 組成を $100 \% \mathrm{Ni}$ とし, 厚さを $100 \mathrm{\mu m}$ とした. 試験片の表面 及ひ断面の組織写真を図 $2(a)$ 及び(b)に示す. 図 $2(\mathrm{~b})$ の 上下方向が圾験片の板厚方向に一致する. また, 試験 片表面の X 線回析結果を, Ni 粉末の X 線回析デー夕 ベース (JCPDS - ICDD) と比較して, 図 2 (dに示す. まず，組織写真から，試験片は，板厚方向に成長した 柱状組織を有し，それと垂直な表面では細い結晶粒が 均一に分布していることがわかる。 また，X線回析結 果から, Ni 粉末の標準データに比べて, 試験片表面 では，(200)面が強い強度で測定されている．このこと から, 本試験片の $\mathrm{Ni}$ 結晶の $4001>$ 方向は, 基板に対 して垂直方向に概ね一致していることがわかる.

図 3 に, Ni 薄膜の結晶構造モデルと, 試験片の $\mathrm{Si}$ 基板に平行な面を「面内（Implane）：1-2面」，基 板に垂直な面を「面外 (Outofplane)：1-3面」と定 義した座標系を示す. 図に示すように, LIGA プロセ スによる Ni 薄膜は FCC 結晶構造を有し, 基板と垂直
方向（Ni 結晶の $4001>$ 方向と一致する）に結晶が成長 した柱状組織となる。このため, 面内（ $\mathrm{Ni}$ 結晶の \{001\}面と一致する）では等方性を示寸が，面外では異 方性を示すことが想定される.

なお，面内または面外押込み試験は，面内（1－2 面）または面外（1－3 面）に球圧子を面に垂直に押 込んで実施するものである。 また, 引張試験では, 試 験片の厚さ方向を 3 方向に一致させ, 荷重を 1 - 2 面 に平行に負荷している.

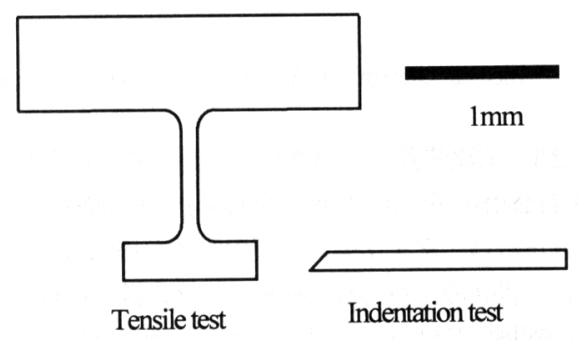

Fig.1 Specimen configuration
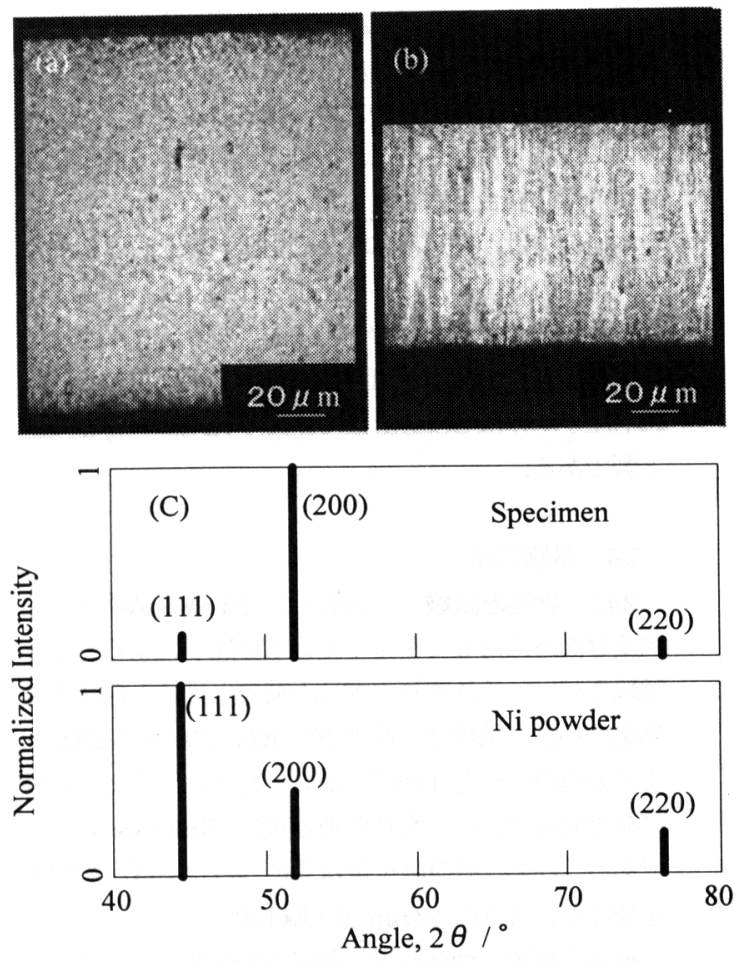

Fig. 2 Optical micrographs of (a) the upper surface and (b) the cross-section and (c) X-ray diffraction result of the upper surface of specimen 


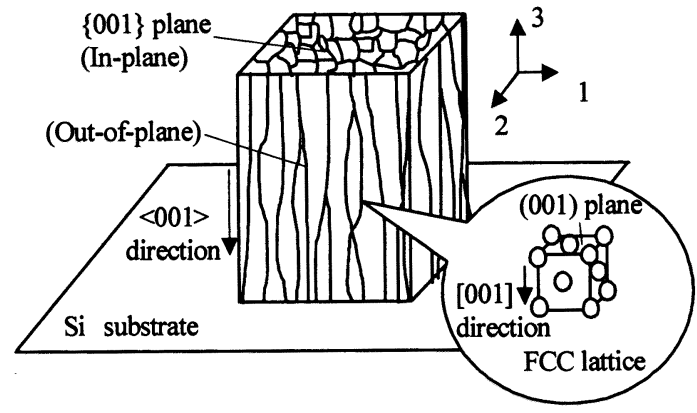

Fig. 3 Microstructure of LIGANi films with a coordinate system

23 試酮装置超微小硬度計（陎島津製作所： DUH-201S）を用いて押込み試験と引張試験を行った. 本硬度計は，ダイヤモンド製の圧子を超低荷重で試料 表面に押込み，得られた荷重一押込み深さ曲線から試 料の機械的特性（ヤング率, 硬さ, 変形抵抗等) を評 価する装置である．試験機の負荷能力は $0.1 〜$ $1961 \mathrm{mN}$ ，押込み深さの測定能力は $0 \sim 10 \mathrm{~mm}$ ，また測 定精度は荷重 $0.2 \mu \mathrm{N}$ ，押込み深さ $0.001 \mu \mathrm{m}$ である．な お, 本硬度計は極めて微小な荷重と変位を計測するた め室内の埃や空気の流れが計測結果に大きな影響を及 ぼす可能性がある.このため, 硬度計はクリーンブー ス内に設置した. さらに，振動の影響を取り除くため 硬度計は防振台上に設置した。

本研究では，押込み試験及び引張試験を行うに当た り，専用の球圧子及び平滑圧子を作製した．球圧子は 押込み圾験用で先端が半径 5.0um の半球，平滑圧子 は引張試験用で先端が直径 $20 \mathrm{~mm}$ の平面である. 何 れも圧子本体は SUS316製で，圧子先端はダイヤモン ド製である。

\section{4 試硂方法}

24.1 押込み試塔 試製した Ni 薄膜試験片の面 内及ひ面外に対してダイヤモンド球圧子による押込み 試験を行い，それぞれの押込み荷重と押込み深さの関 係を求めた。試験は，荷重 $50 ， 100 ， 150$ 及び $200 \mathrm{mN}$ までの負荷除荷を 4 回繰り返して行った. また, 試験 は荷重制御で行い，負荷除荷速度は $70.6 \mathrm{mN} / \mathrm{s}$ の一定 である. なお，各圾験位置は先につけたくぼの影響 を受けないように $100 \mathrm{~m}$ 以上離した。

押込み荷重一押込み深さ曲線の除荷部分からヤング 率を評価する方法として Oliver-Pharr モデル (11)，(1 2)，(14) がある. 本モデルによるヤング率の評価方法 を以下に述べる. 図に示す押込み荷重一押込み深さ曲
線（概念図）において，除荷曲線の勾配（接触剛性） $S$ は試料の複合ヤング率 $E$ と圧子の接触投影面積 $A$ を用いて次式で表される.

$$
S=\frac{2}{\sqrt{\pi}} E^{*} \sqrt{A}
$$

ここで Eは, 試料のヤング率 $E_{S}$ とポアッソン比 $v$, ダイヤモンド圧子のヤング率 $E_{a}=1140 \mathrm{GPa}$ とポアッ ソン比

$$
\frac{1}{E^{*}}=\frac{\left(1-v_{S}^{2}\right)}{E_{S}}+\frac{\left(1-v_{i}^{2}\right)}{E_{i}}
$$

また, $A$ は接触梁さ $h_{A}$ を用いて次式で表される ${ }^{(11)}$.

$$
A=\pi\left(2 h_{A} R-h_{A}^{2}\right)
$$

ここで, $R$ は球圧子の半径, $h_{A}$ は最大押込み深さ $h_{\text {max }}$ 及び $h s$ (除荷曲線の勾配 $S$ と押込み深さ軸との交 点）を用いて,

$$
h_{A}=h_{\max }-\varepsilon\left(h_{\max }-h_{S}\right)
$$

と表すことができる.ここで，\&は圧子形状に依存す る定数で，球圧子では $\varepsilon=0.75$ となる ${ }^{(11)}$. 上記の関 係より試料のヤング率 $E_{S}$ を求めるには，まず得られ た押込み荷重一押込み深さ曲線から， $S, h_{\text {max }}$ 及び $h s$ を求める. $h_{\max }$ と $h_{S}$ を式(4)に代入して $h_{A}$ を求め, こ れを式(3)に代入して $A$ を求める. 求めた $A$ と $S$ を式 (1)に代入し $E$ を求め, これを式(2)に代入すれば試料 のヤング率 $E_{S}$ を求めることができる.

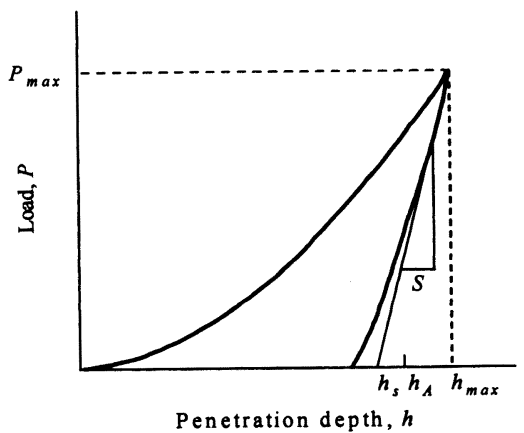

Fig. 4 Schematic of load vs. penetration depth curve in indentation testing 
なお，押込み試験で測定される押込み深さには，試 料の変形量だけではなく試験機フレームの変形量もわ ずかであるが含まれるので, 押込み試験により求めた ヤング率は, 荷重の増加に伴、低下する傾向（荷重依 存性）を示すのが一般的である.このため，押込み試 験によりヤング率を精度よく評価するためには, 荷重 依存性の影響を排除することが重要である ${ }^{(12)}$ 。こ の荷重依存性の大小は, 試験機フレームの剛性により 決まり, 訌験機フレームの㓮性は, 荷重の増加量に対 する試験機フレームの変形量の比の值として定義され るフレームコンプライアンス $C_{f}$ を用いて表される. この $C_{f}$ を試験データから補正することにより, ヤン グ率の測定データに含まれる荷重依存性を取り除くこ とができる．CCを評価するため, 除荷曲線の傾き $S$ の 逆数すなわちコンプライアンス $C(=1 / S)$ と接触投 影面積の平方根の逆数 $(=1 / \sqrt{A})$ をプロットする. このデータは，試験等において誤差がなければ式(1)を 変形して得られる次式を満足し, 原点を通る直線とな る.

$$
\frac{1}{S}=\frac{\sqrt{\pi}}{2 E^{*} \sqrt{A}}
$$

しかし補正前の測定データでは, フレームコンプ ライアンスの影響により原点を通らず縦軸と交差する ことになる. この交点の座標がフレームコンプライア ンス $C_{f}$ である. したがって, OliverPharr モデルにお いて $C_{f}$ を補正するためには，除荷曲線の傾き $S$ を次 式により再評価すればよい。

$$
S=\frac{1}{C-C_{f}}
$$

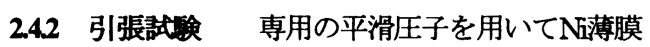
引張圾験片の引張圾験を行い, 面内の降伏応力（図 3 に示すように, 試験片の厚さ方向を 3 方向に一致させ, 荷重を 1-2 面に平行に負荷したときの0.2\%耐力）を評 価した。試験は，負荷速度 $70.6 \mathrm{mN} / \mathrm{s} て ゙$ 試験片が破断す るまで実施した。

引張試験の概要を図 5 に示す. 詿験片の下部は，木 ルダ 1 により保持した. 両者の接合部は, 瞬間接着剤 により固定した. 試験片の上部は, ホルダ 2 により保 持した. 両者の図中Aで示す位置を一致させ, 両者の接 合部は, 瞬間接着剤により固定した. 荷重は, 図中の 矢印方向に, 平滑圧子, プッシャ, ホルダ 1 , 試験片 の順に伝達される.

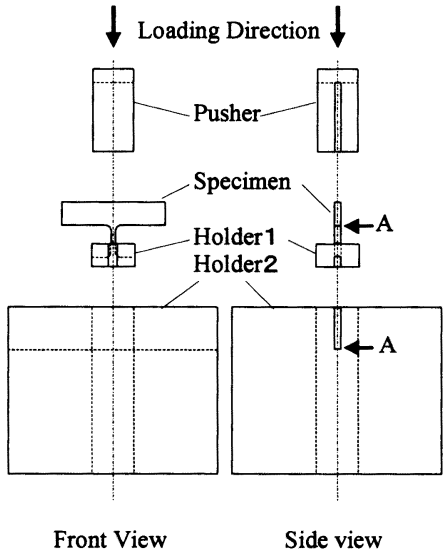

Fig. 5 Schematic drawing of tensile testing

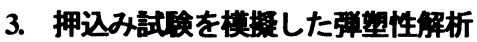

押込み試験の荷重一押込み深さ曲線に基づき降伏応 力を評価する方法が Knapp 等によって提案されてい る ${ }^{(13)}$.この方法は，(1)押込み試験を模擬した弾塑 性解析を行い降伏応力をパラメータとして荷重一押込 み深さ曲線を求め, (2)解析結果と試験結果における荷 重一押込み梁さ曲線の差異を定量的に評価し，降伏念 力の関数としてプロットし, (3)差異が最も小さくなる ときの降伏応力を試料の降伏応力として求めるという 方法である. しかしながら, Knapp らによる方法で は，材料を等方性として解析しているため， Ni 薄膜 のような異方性材料に対しては厳密に適用することは できない. 本研究では大変形解析に適した有限差分解 析プログラム「AUTODYN」を用い， Ni の異方性を 考虑して押込み試験を模擬した弾塑性解析を実施した。 解析において，ダイヤモンド球圧子は，ヤング率： $1140 \mathrm{GPa}$ ，ポアッソン比 : 0.07 の等方性弾性体とし, $\mathrm{Ni}$ 薄膜は, 後述する $\mathrm{Ni}$ 単結晶の弾性定数に基づい, ヤング率: $E_{l}=E_{2}=174 \mathrm{GPa}$ 及び $E_{3}=136 \mathrm{GPa}$ ，ポア ッソン比 : 0.3 の異方性弾完全塑性体とした. また, $\mathrm{Ni}$ 薄膜の降伏応力は, 可変パラメータとして解析を 実施している.

\section{4. 結果及び考察}

\section{1 ヤング率}

4.1 .1 ヤング率の評価 図6及び図 7 に, 面内及 び面外押込み試験で得られた荷重一押込み深さ曲線の 例を示す. 荷重一押込み深さ曲線から, 押込み荷重の 増加とともに押込み深さが深くなり, 完全除荷で大き な永久変形が認められ，荷重レベルによらす除荷曲線 
の傾きが負荷曲線のそれよりも大きくなることがわか る.

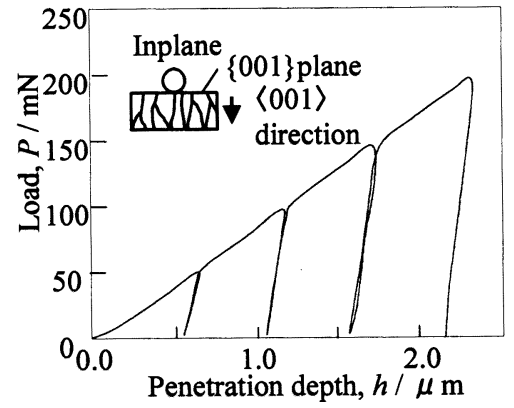

Fig. 6 Load vs. penetration depth curve measured in inplane indentation testing

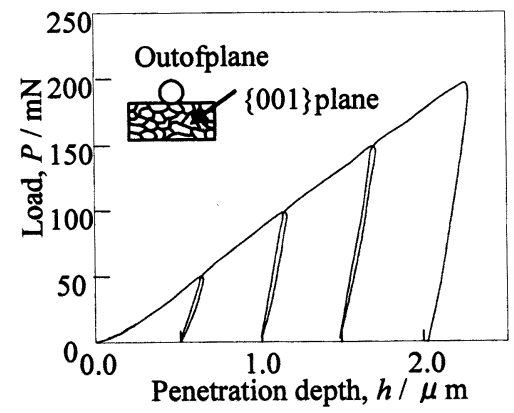

Fig. 7 Load vs. penetration depth curve measured in outopplane indentation testing

OliverPharr モデルによるヤング率の評価において 必要となる最大押込み深さ $h m a x$ と除荷曲線の傾き $S$ を荷重一押込み深さ曲線より評価した. 図8 8 図 9 に それぞれ最大押込み深さ hmax と荷重の関係，除荷曲 線の傾き $S$ と荷重の関係を示す.これらの図中の○ 印が面内押込み試験， $\triangle$ 印が面外押込み試験の結果を 表す．なお，傾き $S$ は除荷曲線の上部 $30 \%$ を直線近 似することによって求めた. 図 8 の最大押込み深さ hmax では, 面内と面外の值は荷重レベルによらずほ ほ一致しており大きな差は認められない，一方，除荷 曲線の傾き $S$ では，両者の值に差が認められる.す なわち面内の傾きがすべての荷重レベルにおいて面外 の傾きよりも約 1.5 倍大きくなる.

次に，測定した最大押込み深さ $h_{\text {max }}$ と除荷曲線の 傾き $S$ を用いて OliverPharr モデルに基づいて，面内 と面外のヤング率を評価した結果を, 図 10 と図 11

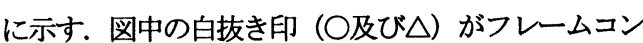

プライアンス $C_{f}$ を補正する前の結果, 黒塗り印 及びム）が補正後の結果を表す，面内と面外のいずれ も $C_{\mathrm{r}}$ 補正後のヤング率は, 補正前に比べて若干大き くなる. 面内及び面外のヤング率の平均值は，それぞ れ $E_{\text {inhme }}=196 \mathrm{GPa}$ 及び $E_{\text {authe }}=142 \mathrm{GPa}$ であり,

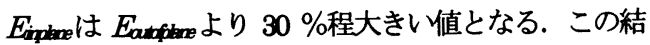
果から，試製した i 薄膜は面内と面外でヤング率の 異なる異方性体であることがわかる. なお，本研究で 求めたヤング率は Buchheit ${ }^{(10)}$ らが押込み試験で求 めた $\mathrm{Ni}$ のヤング率 146〜184GPa と一致している.

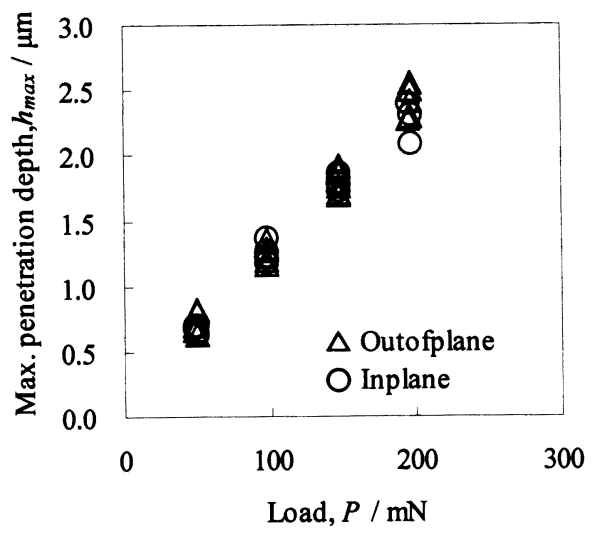

Fig. 8 Relationship between the max. penetration depth which is derived from indentation $P$ - $h$ curves and load

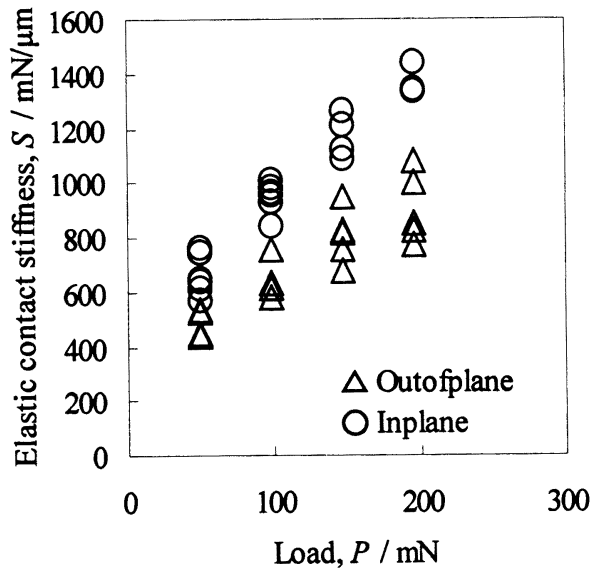

Fig. 9 Relationship between the elastic contact stiffness which is derived from indentation $P$ - $h$ curves and load 


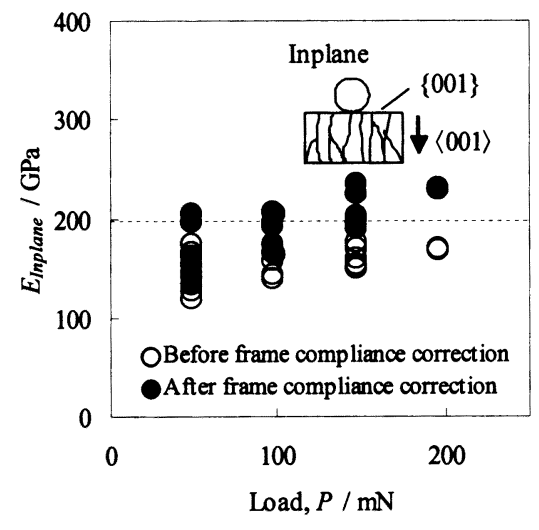

Fig. 10 Measured implane Young's modulus, $E_{\text {rqlone }}$

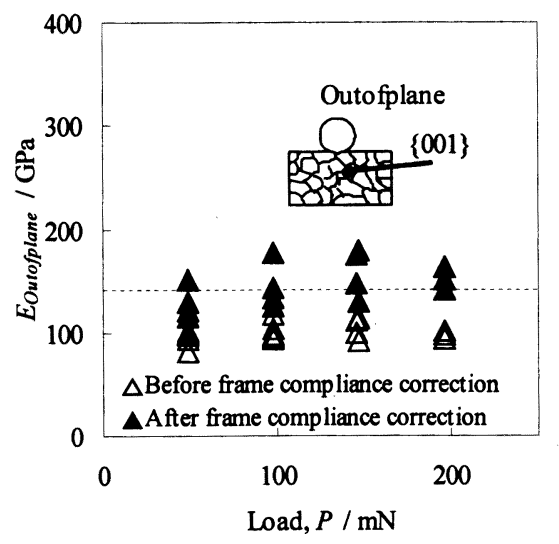

Fig. 11 Measured outofplane Young's modulus, Eampilane

4.12 単結晶 $\mathrm{Ni}$ の絆性定数に基つくくンンク束の評 価本研究で得られた $\mathrm{Ni}$ 薄膜のヤング率の異方性 に関して, 単結晶 Ni のヤング率に基づいて考察する. 単結晶 $\mathrm{Ni}$ の(001)面におけるヤング率は次式により求 められる(5).

$$
\begin{aligned}
E(\theta)= & \left\{S_{11}\left(\cos ^{4} \theta+\sin ^{4} \theta\right)\right. \\
& \left.+\left(2 S_{12}+S_{44}\right) \cos ^{2} \theta \sin ^{2} \theta\right\}^{-1}
\end{aligned}
$$

ここで, $S_{l l}=0.00734 \mathrm{GPa}^{-1}, S_{D}=0.00274 \mathrm{GPa}^{-1}, S_{4}=0.00802$ $\mathrm{GPa}^{-1}$ で, 角度 $\theta$ は(001)面における[100]方向からの角度 を表す. 図 12 に，(001)面におけるヤング率 $E(\theta)$ の方 向依存性を示す.
図から単結晶 $\mathrm{Ni}$ のヤング率は方位により大きく異 なることが分かる. この結果に基づき，LGA Ni 薄膜 の弾性主軸である 1,2 及び 3 方向におけるヤング率 $E_{1}, E_{2}$ 及び $E_{3}$ を評価する. まず, 1 方向と 2 方向の特 性は同一であるので $E_{1}=E_{2}$ となる. また $1-2$ 面（面 内）では結晶がランダムに配向していることから，中 ング率 $E_{l}\left(=E_{2}\right)$ は古典的な平均化手法である Voigt デル (ひずみ一定) 及び Rass モデル (応力一定) に より求めることができる. Voigt モデルと Reuss モデル により求めたヤング率は, それぞれ 17/GPa と 171GPa となり, これらの平均值から $E_{1}=E_{2}=174 \mathrm{GPa}$ となる. また, 3 方向は, N薄膜の厚さ方向, すなわち単結晶 $\mathrm{Ni}$ の $4001>$ 方向と一致する. したがって, $E_{3}=136 \mathrm{GPa}$ となる.

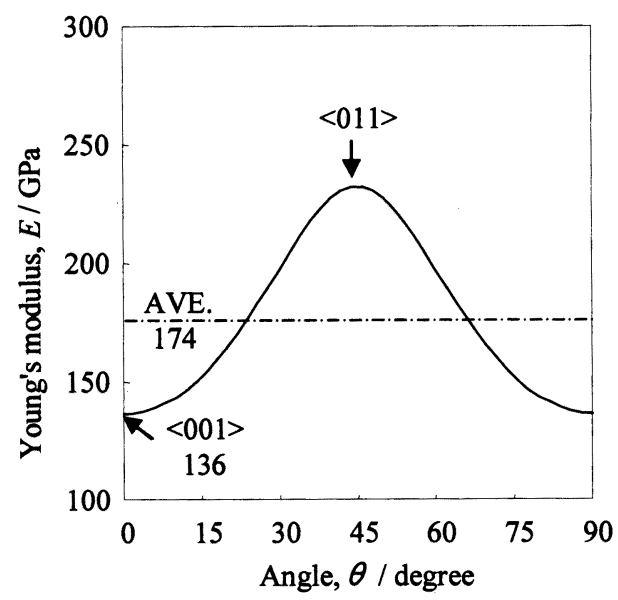

Fig. 12 Young's modulus of single crystalline Ni for the various directions in the (001) plane

続いて，ヤング率 $E_{1}\left(=E_{2}\right)$ 及び $E_{3}$ と，押込み試 験により求めたヤング率 $E_{\text {prne }}$ 及び $E_{\text {auphne }}$ の関係につ いて検討する. 式（1）に示すように，押込み試験に よるヤング率の測定法は, 試料が等方性の弾性定数を 有するものとしており，本来，異方性材料に対して導 き出されたものではない，しかしながら，押込み圾験 は簡便な詿験法であり, 異方性材料のヤング率評価に も一般に適用されている. そのため,ここでは，押込 み試験により測定した異方性材料のヤング率の妥当性 について検証することを目的とする.

押込み試験で測定されるヤング率は, 荷重一深さ $(P-h)$ 曲線の除荷時の勾配に基づいて求めるもので あり,この勾配は試料の弾性定数及び応力場 (応力の 大きさと応力の生じる領域の大きさ）に依存して決ま ると考えられる．押込んだ圧子周りの試料では，塑性 
ひずみと弾性ひずみが生じるが, 圧子荷重を除荷して いくと, 試料及び圧子の弾性ひずみが変化する.この 弾性ひずみ変化により試料の圧子周りが腰長し，この 体積変化量に依存して押込み深さ $h$ が変化すると考え られる。

直交異方性体試料内部の任意位置での体積ひずみ $e$ は, 弾性ひずみの和 $\left(e=\varepsilon_{1}+\varepsilon_{2}+\varepsilon_{3}\right)$ として与えられ, ポアッソン比を一定とすると式(8)で表され, 試料全体 での体積変化量 $\Delta V$ は，式(9)で表される.

$$
e=(1-2 v)\left(\frac{\sigma_{1}}{E_{1}}+\frac{\sigma_{2}}{E_{2}}+\frac{\sigma_{3}}{E_{3}}\right)
$$

$$
\Delta V=\iiint e d x d y d z
$$

式(8)及び式(9)に示すように, 除荷時における試料 の体積変化は, 応力の大きさ, 応力の生じる領域の大 きさ及び弾性定数によって決まるものである.したが っ, 除荷時の $P-h$ 曲線の勾配は, 試料の弾性定数と ともに, 応力場に依存すると考えられるので, 試料の 圧子周りの応力場を明らかにするための解析を行った.

図 13 に, 面内押込み試験を模擬して弾塑性解析 （AUTODYN）により求めた応力（荷重）一押込み梁 さ曲線を示す. 図から, 圧子直下の Point 1 における応 カがそれよりも $3 \mu \mathrm{m}$ 離れた Poin2における值よりも 大きいことがわかる.

図 14 に図 13 と同様の弾塑性解析により求めた除 荷時の 3 方向と 1 方向の応力分布を示寸. 図加 1 方 向の応力が 3 方向の応力よりも大きく, 1 方向の応力 が生じる領域が 3 方向よりも大きいことがわかる.

以上の解析結果より, 除荷時における試料の圧子周 りの応力場は, $\sigma_{l}$ が $\sigma_{3}$ よりも大きさが大きく, $\sigma_{l}$ が生じる領域の体積が $\sigma_{3}$ よりも大きいので, 除荷時 の試料の体積ひずみは， $\sigma_{1}$ の影響を $\sigma_{3}$ よりも強く受 ける. すなわち, 圧子の押込み深さ $h$ が試料の体積ひ ずみに依存すると考えると, $P-h$ 曲線の勾配は $\sigma_{l}$ の 影響を $\sigma_{3}$ よりも強く受け, 同時に, ヤング率 $E_{l}$ の影 響を $E_{3}$ よりも強く受けることになる。

したがって, 面内押込み試験により評価した面内の ヤング率 $E_{i p h r}$ は $E_{1}$ と $E_{2}$ の影響を強く受け，面外のヤ ング率 $E_{\text {amphan }}$ は $E_{1}$ と $E_{3}$ の影響を強く受けると考えら れる. $E_{\text {pqur }}$ と $E_{\text {autohan }}$ に及ぼす $E_{1}, E_{2}$ 及び $E_{3}$ それぞれ の影響の程度は明確ではないが, 面内におけるヤング 率の平均值 $\left(E_{l}+E_{2}\right) / 2=174 \mathrm{GPa}$ 及び面外におけるヤング 率の平均值 $\left(E_{I}+E_{3}\right) / 2=155 \mathrm{GPa}$ は，それぞれ，押込み試
験で得られた面内ヤング率 $E_{\text {ipdre }}=196 \mathrm{GPa}$ 及び面外ヤン グ率 $E_{\text {aufine }}=142 \mathrm{GPa}$ に近い值となる.

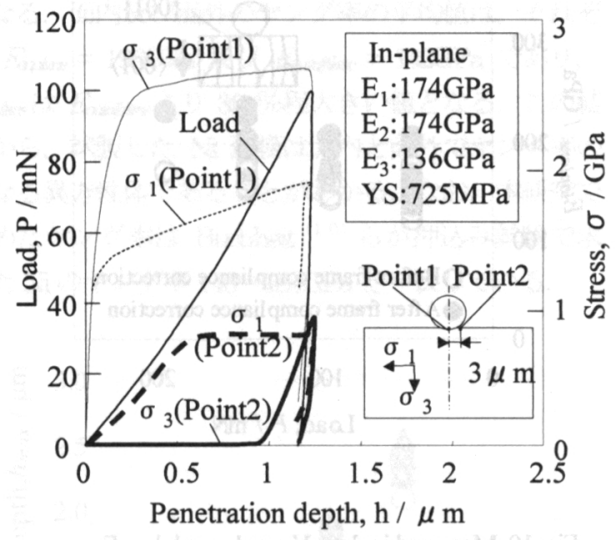

Fig. 13 Simulated load and stress vs. penetration depth curves on the indentation test specimen

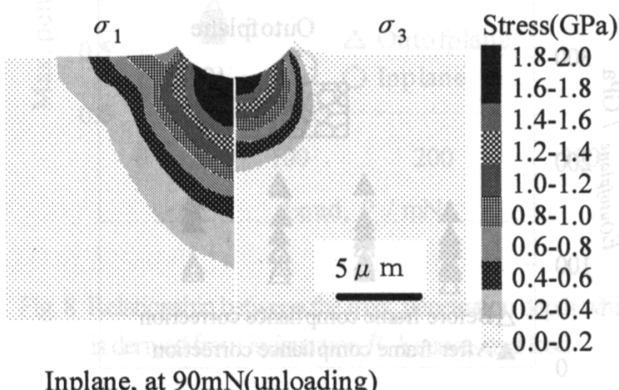

Fig.. 14 Simulated stress contour on the indentation test specimen

42 降伏応力 降伏応力を求めるため, 押込み 試験を模擬した弾塑性解析を行った.

図 15 に，押込み試験で測定した荷重一押込み深さ 曲線と比較して, 降伏応力 $I S$ をパラメータとして AUTODYN を用いて弾塑性解析により求めた荷重一 押込み媣さ曲線を示寸. 図中の細線が解析結果, 太線 が実験結果を表す。また, 実線と点線はそれぞれ面内 と面外の結果に対応寸る. 図から, 降伏応力を変化さ せることにより荷重一押込み深さ曲線が大きく変化す ることが分かる. すなわち, 降伏応力が高くなるほど 変形量は小さくなる. また, 実験結果の荷重一押込み 深さ曲線は, 降伏応力を 650 ８00MPa の間の值とし たときに解析結果と一致することがわかる.

続いて, 解析結果と実験結果の差を定量的に比較し て Ni 薄膜の降伏応力を求める. ここでは両者を比較 するErrorパラメータとして, 


$$
\text { Error }=\left|\frac{h_{\text {mea }}-h_{\text {sim }}}{h_{\text {mea }}}\right|_{\max P}+\left|\frac{h_{\text {mea }}-h_{\text {sim }}}{h_{\text {mea }}}\right|_{\min P}
$$

を用いた，hは押込み深さを表し，添え字の mea と sim はそれぞれ実験值と解析值を意味する．したがっ て, Error パラメータは最大荷重と除荷時の最小荷重 における押込み深さの解析值と実験值の差異を表すも のである.

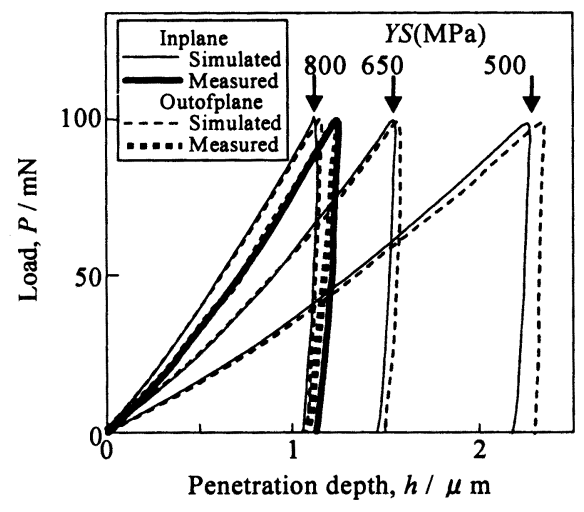

Fig. 15 Effect of yield stresses on the $P$ - $h$ curves

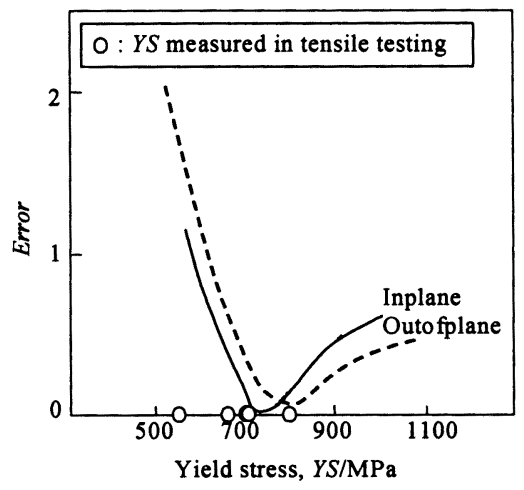

Fig. 16 Error parameter which shows the difference between simulated and measured $P$ - $h$ curves

図 16 に, Errar パラメータと降伏応力の関保を示 す. 図中の実線が面内, 点線が面外の結果を表す. Error パラメータが最も小さくなるときの降伏忘力が $\mathrm{Ni}$ 薄膜の降伏応力となる. 比較のため, 引張試験に より測定した降伏応力（532，661，699，702, $797 \mathrm{MPa}$ ) を図中に示す. 引張試験による降伏応力の
平均值は, $679 \mathrm{MPa}$ となる, 面内の場合, 降伏応力 730MPa において Error パラメータが最小となる.こ の值は, 引張試験で求めた降伏応力 $679 \mathrm{MPa}$ と概ね 近い值である.このことから，押込み試験とともに， これを模擬した弾塑性解析を行うことで試料の降伏応 力を比較的精度良く評価できることがわかる.

\section{5. 結 詥}

（1）押込み試験により評価した LIGA Ni 薄膜の面 内及び面外におけるヤング率は, それぞれ 196GPa 及 び 142GPa であり，弾性定数に異方性を有している.

（2）面内押込み試験により測定されるヤング率 196GPaは，Ni 単結晶\{001\}面における全方向のヤング 率の Voigt・Reuss モデルに基づく平均值 174GPaに近 い值である. また，面外押込み詿験により測定される ヤング率 142GPa は， $\mathrm{Ni}$ 単結晶く001〉方向のヤング率 $136 \mathrm{GPa}$ と\{001\}面におけるヤング率 $174 \mathrm{GPa}$ の平均值 155GPaに近い值である.

（3）押込み試験とそれを模擬した弾塑性解析により, Ni 薄膜の降伏応力を求めることができる.

\section{6.文㙎}

（1）服部正，日本機学会機械材料・材料加工部門ニュースレ ター, $26(2003), 2 \cdot 3$.

（2）羽賀剛ほか，MES2001（第11回マイクロエレクトロニク スシンポジウム)，(2001), 291-294

(3) S. Sundararajan etal, Sensors and Actuators, A101(2002), 338.

(4) X Liet al, Surf Coat Tech, 163-164(2003), 521.

(5) K J. Hemker et al, Materials Science \& Engineering, A319$321(2001), 882-886$.

（6）土屋智由，豊田中央研究所 R\&D レビュー，34-1(1999)， 25-30.

(7) T. Tsuchiya et al, J.Microelectromech. Syst., 7(1998), 106.

(8) M. Haque al, J.Microelectromech. Syst, 10(2001), 146.

(9) W. Sharpe et al, J.Miczoelectromech Syst, 10(2001), 317.

(10) M Gad-El-Hak, The MEMS Handbook, (2002), 3.18 - 3.20, CRCPRESS

(11) E. G. Herbertet al, Thin Salid Films 398-399(2001), 331-335.

（12）澤健司ほ力，IDEMAJapan News，40(2001)，13-17.

(13) J. A Knapp et al, Surface and Coatings Technology, 103104(1998), 268-275.

（14）中上昭光ほか，Kobe Steel Engineering Reports，52-2 (2002),74-77. 